\title{
Using Local Rural Knowledge to Enhance STEM Learning for Gifted and Talented Students in Australia
}

\author{
Julia Morris ${ }^{1}$ (D) Eileen Slater ${ }^{1} \cdot$ Michael T. Fitzgerald $^{1} \cdot$ Geoffrey W. Lummis $^{1}$ • \\ Eddie van Etten ${ }^{2}$
}

Published online: 31 January 2019

(C) The Author(s) 2019

\begin{abstract}
In order to supply a future Science, Technology, Engineering, and Mathematics (STEM) workforce, Australia needs to engage its most capable and gifted secondary students in quality STEM learning, either within school or through extra-curricular opportunities, so that they will continue into STEM-based tertiary degrees. High-achieving students in rural communities may face additional barriers to STEM learning that can limit their ability to pursue advanced STEM studies and occupations. This small-scale research project sought to explore a group of gifted lower secondary students' engagement and experiences in a STEM programme designed around a local rural knowledge model as reported by Avery (2013), which uses local knowledge as a vehicle for science learning. This multi-method study was conducted with 26 students years 7 and 8 in a rural school. Information about students' general science class experiences were collected quantitatively. These experiences contrasted the local rural knowledge programme, where the students worked with an ecologist and experienced science educators to rehabilitate small plots of damaged land close to the school site. Qualitative data were collected throughout the programme to determine its influence on students' engagement and learning in STEM. The research found that the local rural knowledge model enhanced students' engagement in STEM learning and they felt that they retained knowledge better as a result of the authentic learning experience. Students also engaged the wider community in the process, leading to broader translation of the STEM learning.
\end{abstract}

Keywords STEM · Gifted and talented education · Inquiry science education · Rural education

Julia Morris

j.morris@ecu.edu.au

1 School of Education, Edith Cowan University, Joondalup, WA 6027, Australia

2 School of Science, Edith Cowan University, Joondalup, WA 6027, Australia 


\section{Introduction}

International reports and studies commonly find that rural, remote, and regional students underachieve compared to their urban counterparts. The Organisation for Economic Cooperation and Development (OECD) (2016) found that students from rural areas were more likely to be delayed in terms of progression through learning. In the USA, rural students have been deemed as disadvantaged in terms of schooling funding and student enrolment in tertiary education (Schafft and Jackson 2011) and similar conclusions have been found in India and Pakistan (Alcott and Rose 2015). It is clear that this is a common thread throughout education systems around the world.

In 2017, the Australian Government announced an independent review in the state of regional, rural, and remote education. This review is aimed at identifying key challenges that impact educational outcomes for students outside the metropolitan area, given that "test results in Australia and from overseas show a significant difference in educational achievements of Australian regional, rural and remote students compared to their city peers" (Halsey 2017, p. 15). Consequently, addressing educational disadvantage for Australian students in rural areas is of importance, especially in meeting the Melbourne Declaration's goals for all students to be successful learners who are motivated to reach their potential, and in ensuring "that socioeconomic disadvantage ceases to be a significant determinant of educational outcomes" (MCEETYA 2008, p. 7).

Avery (2013) cites local rural knowledge (LRK) as one strategy to increase educational outcomes within broader rural areas. LRK is student-centred knowledge that is specific to their community and the community's unique identity and culture, consistent with the notion of science as a human endeavour (ACARA 2015). LRK can be used to engage secondary school students in authentic STEM inquiry. The lived experience of rural students provides a rich environment for STEM learning, as teachers can begin to show students "the relevance of science to their daily lives [so they are able to] connect the STEM they learn inside and outside school" (Avery 2013, p. 30).

This small-scale study explored LRK in a rehabilitation programme of work with lower secondary students in a rural Australian secondary school. In the LRK programme (referred to as the programme), the students explored issues of land rehabilitation as an outcome of mining. The programme was conducted with a group of gifted and talented students, as these students are often hidden in achievement reporting for rural schools (Halsey 2017). In addition, there is limited literature relating to STEM education for formally identified gifted students in Australia. Much of the research in gifted education is related to the characteristics of gifted students as learners (Walsh et al. 2012) as opposed to their STEM educational outcomes, and research linking the effective transfer of knowledge about gifted learners to a generic model of STEM curriculum programming and a subsequent positive affect on the retention of students in STEM subjects is yet to be reliably established. Consequently, this study explored how LRK might be utilised to improve STEM educational outcomes for this group of students, who are labelled as disadvantaged within the Australian educational system as confounding variables often result in these students being categorised as students at educational risk within the current system (Halsey 2017). Specifically, the study aimed to investigate how foregrounding LRK impacted on students' engagement and learning in STEM by first surveying the types of learning experiences that occurred within the students' typical science classroom, and second, by qualitatively evaluating their experiences of an authentic (as it would occur in society) LRK-driven programme of work. 


\section{Literature}

\section{STEM Education}

The recruitment and retention of students into Science, Technology, Engineering, and Mathematics (STEM) careers, as well as the development of STEM skills and appreciation within the general populace, has been a continued focus worldwide (National Science Board 2014; OECD 2016), as well as in Australia (Marginson et al. 2013; Office of the Chief Scientist 2014). The STEM acronym is used in the Australian context to define future workforce roles and student learning opportunities which require the integration of Science, Technology, Engineering, and Mathematics skills. The reality that Australia is not on target to meet the future Science and Mathematics needs identified in these reports is illustrated in the country's declining performance in The Programme for International Student Assessment (PISA) (Thomson et al. 2016a) and the Trends in International Mathematics and Science Study (TIMMS) (Thomson et al. 2016b). Between 2006 and 2015, when science was the focus measure in PISA, six of the eight jurisdictions in Australia showed a significant decline in scientific literacy; a similar decline in mathematics occurred between 2003 and 2012 in seven of the eight jurisdictions (Thomson et al. 2016a). In rural locations, students dramatically underperform in science assessment data compared to their metropolitan peers (National Assessment Program: Scientific Literacy, 2003-2012). In part, this may be due to the nature of teacher capacity, training, and retention in rural areas (Townsend et al. 2016).

While performance in STEM subjects is an area of concern, there is evidence of increasing STEM subject engagement by secondary students (Christensen et al. 2015). Innovations are arising in STEM education which promote a deeper understanding of the interdependent nature of Science, Technology, Engineering, and Mathematics through links to authentic contexts (Akerson et al. 2018; Means et al. 2017; Parker et al. 2016). STEM pedagogies that are centred on inquiry-based, problem-based, and collaborative learning across disciplines (Chiu et al. 2015) have been associated with higher STEM dispositions (Christensen et al. 2015), are more authentic to STEM careers (Chiu et al. 2015), and have been shown to promote deeper levels of problem-solving and higher-order thinking in students (Johnson et al. 2015). These types of educational programmes show promise in raising the recruitment into and retention of students in STEM subjects.

\section{Gifted and Talented Education and STEM}

Engaging with challenging, meaningful content is an essential element for gifted learners to successfully engage in STEM-related subjects (Siegle et al. 2014). Gifted students dislike repetition, a consequence of exceptional memory (Cohen and Sandberg 1977; Croft 2003; Freeman 1985; Guilford et al. 1981; Harrison 2004) and prefer content at a faster pace that enables them to make connections between different concepts or subject areas, orientating information in "the bigger picture" (Davidson 1986; Merrick and Targett 2004; Parkinson 1990). Gifted students favour authentic learning in STEM subjects that bring meaning to the content, either personally or contextually.

Gifted learners are responsive to a degree of autonomy over their own learning, including learning in STEM subjects (Mullet et al. 2018). This allows the students a degree of choice and autonomy over the depth and breadth of the content, the learning processes used, and the application of creativity, aligning well with the National Research Council (2002) 
recommendation of a student-centred approach to teaching STEM. Mullet, Kettler and Sabatine (2018) report that gifted students are often not supported in this way in their STEM classes, with teachers deferring to delivering essential content. This is supported in the Australian context by Danaia et al. (2013) study, which indicated very little inquiry-based science teaching occurs in Australian secondary classrooms, despite calls to attain the ideal picture of school science (e.g. Rennie et al. 2001; Tytler 2007) and evidence that this approach works in an Australian and international context (Danaia et al. 2017; Lazonder and Harmsen 2016; Skamp 2012).

Students have linked positive STEM self-efficacy to positive experiences in STEM subjects. Gifted students cite increased positive self-efficacy in STEM subjects as a result of mastering previously challenging topics or tasks through persistence, while willingness to persist has been linked to positive self-efficacy (Dieker et al. 2012; Hertzog 2003; Mullet et al. 2018). Thus, there is a self-perpetuating formula if teachers can find ways to increase gifted students' STEM self-efficacy.

The barriers to teachers implementing quality science education in their classrooms are numerous, even in an urban environment (Fitzgerald et al. 2017). The rural context exacerbates these issues. Transient teaching populations (Monk 2007), teachers with less subject specialisation (VanTassel-Baska and Hubbard 2015), and a lack of access to pre-service (Taylor and Milton 2006) and in-service (Croft and Wood 2015) professional learning in gifted education have all been sighted as contributing to the increased barriers to providing positive STEM learning opportunities for gifted students in rural communities. In light of this, any STEM educational programme for gifted students in a rural setting needs to ensure access to subject specialists and experienced education specialists in order to maximise the engagement of gifted students (Siegle et al. 2014) and further support and develop rural teaching staff.

\section{Sustainability and Environmental Education}

This research study was centred in sustainability as a context for STEM, as it linked to the global consciousness and social justice values often reported by gifted students (Harrison 2004). Sustainability is an area of interest in Australian education, evidenced by its inclusion as a cross-curriculum priority where it is defined as encompassing interactions between social, economic, and environmental systems to support sustainable development (Australian Curriculum, Assessment and Reporting Authority [ACARA] n.d.). As a priority, teachers are directed to integrate sustainability where it aligns to their teaching in each learning area (ACARA n.d.). Sustainability education has an evolving history linked to the early environmental movement, despite becoming more popular within the last decade (Lummis et al. 2015).

Sustainability is of increased importance to students in rural areas, particularly in Australian communities affected by mining. Students in rural areas observe the economic opportunities and significant ethical responsibilities for Australia from mining through their lived experiences, as many of these students have parents employed by mining (Flannery 2010). Many students in rural Australia will also see the export of many billions of dollars of resources including fossil-based energy and metal commodities to Asian economies (Department of the Environment and Energy 2017; Department of Foreign Affairs and Trade 2017). As students often develop their understandings about sustainability through engagement with mass media and interpersonal interactions with family and friends (Odgaard 2014), it is imperative for teachers to ensure that sustainability is appropriately addressed in education so students develop a deep awareness of all pillars of sustainability (Dyment and Hill 2015). These pillars 
include the following: an end to poverty, social inclusion, addressing the environmental agenda, and ensuring good governance that exists to support the other pillars (Sachs 2012). Students in rural contexts will share communities with Aboriginal and Torres Strait Islanders and their elders who have ongoing concerns regarding the loss and rehabilitation of Country. Consequently, sustainability, and environmental education is embedded within their daily lives.

\section{Local Rural Knowledge Model}

The approach taken in this research reflects the local rural knowledge (LRK) model by Avery (2013), and as such, the LRK model was applied as a theoretical framework. The LRK model was conceptualised as being sensitive to the place-based nature of most rural students' lives and the particular context they reside in. In particular, this is marked by relative isolation, underfunding and higher costs borne by rural schools, difficulties in attracting school personnel, a lack of STEM role models and a culture of "learning to leave" where students expect to leave their rural community to succeed in their studies and careers (Avery 2013; Sipple and Brent 2008; WIlliams 2010). Avery's (2013) research found that bringing local rural knowledge into the classroom created a positive learning environment juxtaposed the perception of inherent disadvantage within the rural setting. Instead, LRK respects the life experience of rural students and community members and builds on this knowledge, promoting the types of authentic learning that are often attributed to STEM (Avery 2013; Christensen et al. 2015).

In the context of this study, the LRK experienced by students included making connections to local indigenous knowledge as well as knowledge of the mining context and its impact on the local land as part of a land rehabilitation learning programme. Consequently, the LRK was centred in sustainability and this was used as the context for STEM teaching and learning. In particular, this study focussed on implementing three pedagogical strategies attentive to LRK as suggested by Avery (2013) in her teacher level of the model. The first was "Teacher Place Based Professional Development", where teachers are exposed to local and indigenous knowledge through their experiences, leading to the legitimisation of this knowledge. It is important to note that the term professional development does not refer to a one-off professional learning experience, but instead refers to the collection of teachers' experiences that lead them to integrating LRK in their practice (Avery 2013). This strategy is about the planning stage, ensuring that programmes of work promote LRK within a positive school context (Avery 2013). The second was "Scaffold Content and Pedagogy", where LRK is explicitly integrated with the curriculum standards to enhance student engagement (Avery 2013). The third was "Provide students with concrete experiences", so that the students engaged with their local environment and issues that directly impact their community. This pedagogical strategy is about making connections beyond the school environment, broadening learning into authentic community contexts (Avery 2013).

\section{Methodology}

The research used a multi-method design (Morse et al. 2006), comprised of a quantitative phase to identify pedagogy and practice in the science classroom prior to the programme, and followed by a qualitative phase that explored the impact of the local rural knowledge (LRK) programme on the students' engagement. A multi-method design was appropriate as each 
phase of the research was driven by a different theoretical thrust. The initial quantitative phase was deductive in that it measured the state of play of the science learning for the sample, using an instrument that was developed to assess the quality of science education in Australia (Goodrum et al. 2012).

The follow-up qualitative component was inductively driven, as the aim was to explore the programme design and its impact on student engagement in STEM. A constructivist framework was used in this phase as the student participants co-constructed knowledge along with the researchers and teachers throughout the shared learning experience (Punch 2014; Schwandt 2000).

Each phase of the research was treated independently. The quantitative data did not alter the intended programme, but instead provided a snapshot of the classroom activities so that the researchers could identify how the programme was different to the lived experiences of the students. Ethics clearance from the university's Human Research Ethics Committee was provided prior to any data collection.

\section{Participants and Research Context}

The small-scale research study was conducted in one school with a total of 21 female and five male lower secondary students in years 7 and 8 (12 to 13 year olds) who were identified as academically talented and part of an academic extension programme. Similar to many Australian gifted and talented education programmes, these students were accepted into the programme after academic testing, as well as on teacher recommendation and past academic achievement evidenced in school reports (Fitzgerald et al. 2017).

While the term rural will be used throughout the paper due to its synergy with the LRK model, the school site for this study was defined as remote using the Australian Bureau of Statistics Remoteness Classification (Australian Bureau of Statistics 2011). The school was located in a remote town in a mining area, and consequently, many students who participated in the study had family members who worked in the mining sector. As such, there were issues of transience in the community and also rehabilitation issues for the land disturbed by mining. The remote town also has a large Indigenous population.

\section{Research Design and Instrumentation}

The first phase of the multi-method design was the dissemination of the secondary school science questionnaire, used in The Status and Quality of Year 11 and 12 Science in Australian Schools report by the Australian Academy of Science (Goodrum et al. 2012). This questionnaire is a diagnostic tool designed to explore students' experiences and engagement with science in the classroom context. For example, the questionnaire asks students to rate how frequently they undertake experiments, work in groups, or take notes. It also begins to probe for student engagement in terms of asking students about their emotional response to science (e.g. excitement, boredom) as well as including some text-based questions where students can identify what they like and dislike about science as well as explaining why they think they do science at school. The secondary school science questionnaire was implemented in phase one to collect data on the science lesson experiences of the students. These data were used to determine the extent to which the LRK programme differed from the general science lesson experience within this sample. 
The second phase of the research was qualitative in nature, and multiple sources were used to capture the students' experience as well as its effect on their engagement and learning. The students worked with a team of science educators, scientists, their science teachers, a local indigenous elder, and local industries to plan and then conduct a land rehabilitation project. The context for the programme was the rehabilitation of degraded land inside the limits of the local town site. Access to the land was negotiated with the appropriate government authority, which provided information on prior and future use. The students were responsible for selecting and rehabilitating a small plot of degraded land in groups of three. The small plots of land were made up of 25 square metre plots over varying terrain types.

Collaboratively, students physically defined, measured, and surveyed their chosen plot. The students measured and assessed soil conditions, identified viable local plant species from a scientific and local indigenous perspective, collected seeds (under licence), and raised plant saplings through soil banking. The students chose and prepared seeds for planting, testing a variety of methods to encourage germination, and prepared the soil based on their groups' soil assessment. After a few months, the students were taken back to their plots to ascertain the progress or each plot by estimating the percentage of successfully rehabilitated area, considering each sample of individual plant species performance.

At the next point in the rehabilitation process, students were given a tour of a local nursery that specialised in local native plants run by an indigenous group who shared their operational process with students and described each of the species available. Students then decided how to spend their individual budgets to support the further rehabilitation of their plot in response to their most recent statistical assessment of its progress. Throughout the rehabilitation project, local industry monitored the development of the students' plots and shared progress images with the school and university.

Over the duration of the research, students' interactions with the land and other participants were observed by researchers, with observations recorded as field notes. Photo documentation was used by the students to capture the experience from their perspective as participant, similar to Avery (2013). Focus groups were conducted with the students at the end of the programme experience to co-construct knowledge of the students' engagement levels and gain deeper understandings of how the experience linked to LRK and STEM. The students also provided written feedback on the experience.

\section{Analysis}

The quantitative data from the secondary school science questionnaire were analysed using IBM's Statistical Package for the Social Sciences (SPSS) Version 24, with descriptive statistics computed to show the "typical" science classroom experiences for the students within this study.

The qualitative data were deductively coded after a contracted transcriber returned verbatim transcript recordings of the focus group. The transcripts were added to the full data set, which included the students' written feedback, researchers' field notes, and photographic evidence. The variety of data sources allowed for triangulation and also increased credibility, as the sources were taken from multiple perspectives (student, staff, and researcher). The analysis employed a thematic approach that generated codes based on reading the full dataset, using the LRK model as a framework for coding (Miles and Huberman 1994). These data sources were analysed by two members of the research team, who then employed member checking with the remaining research team members for credibility. Using this approach allowed codes to be 
compared over time and multiple readings of the qualitative data set. The coding showed clear synergies with Avery's (2013) LRK research, and this model is employed throughout the presentation of findings for phase two.

\section{Results: Phase One}

The first phase of the research collected quantitative data to examine the typical science education experiences of the years 7 and 8 academically talented students in the school. Table 1 shows that these students enjoyed conducting experiments in science. When looking deeper into the nature of experiments as a pedagogical teaching strategy through the Likert scale questions, it becomes evident that while experiments are conducted and enjoyed by the students, they are only rarely or never experiments which have been designed by the students themselves. Ninety-two per cent of students responded that the teacher never (56\%) or sometimes (36\%) allowed them to "design and do their own experiments". Furthermore, the Likert scale responses indicated that science is something that happens inside the classroom, with the students responding that science lessons were never $(80 \%)$ or sometimes $(20 \%)$ held outside the classroom in the bushland or on school grounds. There was very limited evidence that links to the local community were being made during science lessons, with all students responding either never (92\%) or sometimes (8\%) to the statement, "For science we have excursions to places in our community". Twenty-four per cent of students enjoyed learning new things in science, for example, "I like science lessons because I am fascinated by the way everything works in the world and I like learning new things that help to explain how things work ..." (student 13).

While $24 \%$ of students felt that the teacher was "good" at helping them to understand the science content, a further $28 \%$ of students did not like science "when the concepts are too hard to understand" (Tables 1 and 2), suggesting that there is a content that is never mastered by more than one quarter of the participants. These two contrasting response types suggested that the range of abilities in the class was quite diverse. In addition, $28 \%$ of students made reference to classroom management issues being a problem in science; for example, student 8 stated, "I don't like how in our experiments some students are always mucking around", while student 9 stated, "I don't like when the class talks during science lessons because it makes it hard to concentrate on what the teacher is saying". Student 22 commented, "Sometimes people have to wait a long time because they are finished while other people are trying to finish", which is both a classroom management issue and offers further evidence of diversity within the class. The students disliked worksheets (8\%), working from textbooks (12\%), and copying of notes (20\%). Student 6 stated, "we have a lot of homework and worksheets", while student 25 commented, "I don't like doing work from a text book because it is boring!!!" Student 12's comment exemplifies those made about coping notes, "[I don't like] how Mrs X sometimes makes us write a lot of things from the board".

Table 1 Frequency of responses to the item "What do you like about Science?"

\begin{tabular}{lcc}
\hline Theme & Count & Percentage \% \\
\hline The teacher's use of humour. & 1 & 4 \\
I like learning new things. & 6 & 24 \\
The teacher's ability to help me to understand. & 6 & 24 \\
I like doing experiments. & 15 & 60 \\
\hline
\end{tabular}


Table 2 Frequency of responses to the item "What don't you like about Science?"

\begin{tabular}{llc}
\hline Theme & Count & Percentage \% \\
\hline There is nothing I do not like. & 2 & 8 \\
Too much time filling in worksheets. & 2 & 8 \\
Constantly working from textbooks. & 3 & 12 \\
Copying of notes (writing). & 5 & 20 \\
It is boring. & 5 & 20 \\
When the concepts are too hard to understand. & 7 & 28 \\
Classroom management problems. & 7 & 28 \\
\hline
\end{tabular}

When asked why they thought they learnt science at school, the students demonstrated deep understandings of the necessity to learn science (Table 3), with $72 \%$ of students linking science education to a better understanding of the world around them. This is exemplified by student 19, "Everybody uses science in their everyday life so understanding science is important to everyone" and student 13, "Science is a very important subject. Science is used in everything and it is the reason that we are able to find out new things about the world". A further $40 \%$ of students recognised that their future education and employment opportunities would require science understandings. Student 10 stated, “... as we progress with our future, the more science jobs are needed".

Considering the students' emotional response to science in their responses, $84 \%$ of students indicated that they were never $(24 \%)$ or sometimes $(60 \%)$ bored, while the remaining $16 \%$ of students felt bored during most (12\%) or every (4\%) lesson. These statistics were supported by the responses to questions about science classes' evoking curiosity and excitement, with only $12 \%$ of students indicating that they were "never" curious "nor excited in science class". The endorsement of the affective statement "during science lessons I am confused" also supports earlier evidence that the range of abilities in the group was large, with $20 \%$ of students indicating confusion in most classes $(12 \%)$ or every class $(8 \%)$.

\section{Results: Phase Two}

The second phase of the research involved the rehabilitation LRK programme. Following Avery's (2013) LRK model at the teacher level, there were three identifiable strategies within this phase. First, teacher place-based professional development occurred through the mentoring of school science teachers. These teachers worked alongside the university science educators, who had extensive experience in gifted education, as well as scientists, in the programme. They also learnt about the place-based model and how LRK was being implemented into the learning experience through the process. Second, scaffolding of content and pedagogy was established through the connection of LRK with appropriate science curriculum content, with the programme of work being

Table 3 Frequency of responses to the item "Why do you think you learn Science at school?"

\begin{tabular}{lrr}
\hline Theme & Count & Percentage \% \\
\hline Science brings joy to some people. & 1 & 4 \\
You need science for future education and employment opportunities. & 10 & 40 \\
Understanding science is important to humanity's future. & 5 & 20 \\
Science helps you to understand the world around you. & 18 & 72 \\
\hline
\end{tabular}


co-written by university and school staff, based on shared understandings of Avery's model. Third, students were provided with concrete experiences, as evidenced by the hands-on authentic science experiences conducted on the degraded land that they rehabilitated.

\section{Teacher Place-Based Professional Development}

Avery's (2013) LRK model begins by addressing the need for professional learning so teachers are aware of how LRK can be integrated in science education for rural students. While the study only explicitly gathered data from the students, anecdotal evidence suggests that the programme impacted the Head of Learning Area's pedagogy, evidenced through conversation with the research team. The researchers observed that the Head of Learning Area was very active in the programme phase of the research and often engaged with the students and staff members throughout the process. The school science teachers were involved in every stage of the programme; helping to co-write the learning programme, organising the field trips to the damaged land, co-teaching the learning programme, and participating in the activities with the students. Consequently, these activities promoted the positive inclusion of LRK in students' learning and supported teachers' in the inclusion of LRK in their planning. Professional learning primarily occurred through the embodied experience of the programme, which not only promoted place-based values but also extended to the modelling of science inquiry. For example, it was noted that in relation to science inquiry skills, the teachers were confused in differentiating between dependent and independent variables. There was also evidence of inappropriate modelling of question and hypothesis writing, whereby the hypothesis did not contain both the dependent and independent variables. In the co-teaching environment, university staff was able to model pedagogical strategies around differentiating between dependent, independent, and controlled variables and the writing of measurable hypotheses to both staff and students.

In this research, the student focus groups triangulated the findings from the quantitative phase and identified the need for a new approach to science education. The students explained, "I like it when we do experiments because we rarely do that" and "we just read through the chapter [in our textbook] and then answer the questions at the back". They began to identify how textbook-centred work had limitations; "If you work out of a textbook you wouldn't actually see how it works or anything, and by doing it you get to see what happens and the effects". Their responses highlighted a need for professional learning to occur in the programme, moving from didactic to more inquiry-based pedagogy.

The students noticed the difference in science learning after the programme saying, "we can walk around, it's more fun. We actually get to do something instead of just writing in our books, which is kind of cool". Another student explained how they felt they were learning "more":

Plus you're more likely to learn more and trust the evidence. Like learning in a textbook, it's just routine for you; you read, you answer the questions and that's it. When you actually get onto the site, get your hands dirty, get in there and really solve it, it stays with you and you get more interested in the subjects as well.

Observation data showed that the teachers were beginning to integrate place-based inquiry pedagogies into their practice throughout the programme. They began to voice other opportunities to connect science with the local community, such as a co-constructed community edible garden and making links with local industry to develop the students' chemistry 
knowledge. LRK was modelled through the authentic learning that occurred on-site throughout the rehabilitation project, which was a new strategy for the teachers involved in the study and evidenced in the students' reflections both pre and post programme.

\section{Scaffold Content and Pedagogy}

The aims of the research were more closely aligned with the scaffold content and pedagogy strategy of Avery's (2013) LRK model. This strategy seeks to integrate LRK with the curriculum standards to enhance student engagement (Avery 2013). As outlined previously, the students identified the pedagogical shift between their "typical" lessons and the LRK programme experience. In reflecting on the experience, they identified that it was a student-centred learning experience. Students spoke about their affective response to the learning experience; "It's a lot more interactive and it means that I'm like learning more and I'm more open to like everything". This openness was often linked to statements on autonomy, such as "I liked going and seeing the progress of the plants and stuff. I liked that we got to choose like our own stuff to plant". The students often spoke about the class as a community, despite the fact that they were working in small groups on individual plots. The students could explain similarities across the plots:

Every group's plot differed about the elements they lacked ... Most of the class lacked the majority of the elements ... The majority of the class lacked nitrogen and potassium whereas phosphorus levels for the class depended on the individual groups on where they placed it because some had really high levels of phosphorus, others didn't.

They also explained how they worked collaboratively; "most of the class really enjoyed it. Everyone liked going out to different sites and were like, 'hey can I help and like, you should probably like dig the hole circular or something"'. The pedagogy had changed from teachercentred to student-centred, and the students responded positively to this change.

The students were also making connections between the content of the learning experience and the wider community. They began to talk about the importance of land rehabilitation after mining, saying "I think wherever people mine they should like, after they've finished with the mine, they shouldn't just leave the mine open. They should fill it back in or something". They also spoke about what would make their experience easier and commented on how the damaged site (which had some weeds) had made the rehabilitation process more challenging:

[Miners should] have new plants over it [the land left after mining] because then the soil would be refreshed and stuff, because it will have gotten air to it while they were digging it out and stuff. And so it would probably be easier for people to plant stuff in it. So it wouldn't be as compact and hard to dig through.

Importantly, the students began to think critically about the process they were undertaking. The students had an issue with seeds dying over the school holidays and felt that the timing of rehabilitation processes should be considered as part of their planning:

I think it would be better in the winter if we did it because then when we went out and collected the seeds it could have been easier for us to get seeds ... instead of relying on the professors and the university to supply us with [more] seeds because in the winter it's cooler.

They also deepened their understanding on growing plants within the local conditions: "I used to think if most plants wouldn't be able to grow in this climate because of the heat. I didn't actually know it had something to do with the soil condition”. 
Students expressed a number of ways they could extend the project through inquiry science. They thought about scattering the plots on the damaged site to look at the effects of plot location on the success of rehabilitation; "where our plots can be separated differently instead of being so close to each other because I think then you could get different examples and different results for how our experiment worked". Students suggested more time spent researching and understanding key elements, such as the needs of individual plant species including root systems and water and soil requirements would have allowed them increased opportunity to apply knowledge they had gained through experimentation. This suggested that students saw the benefit of the experiments that they designed and conducted around germination and soil type and envisaged further opportunities to maximise this strategy. Examples included the following:

I would have liked to learn even more about the individual plants before planting them particularly their root system and the amount of water they required as well cos [sic] that might have helped with like seeing where I'm putting them and I could have applied my knowledge.

I guess I would have liked to learn a bit more about the soil conditions needed for plants to thrive here like where you actually put the seed in the layers of the ground, if that actually does affect how the plant grows if you put it really deep down or really close to the surface. It would have been interesting to do as an experiment.

One student suggested looking outside the local area and experimenting with species which may be able to grow in the local conditions; "Try adding different plants in different places. Yeah, to see if some of the flowers and stuff from [other major cities] like hibiscuses and stuff would grow ... seeing what other conditions they could survive in. See if they could adapt".

The students' responses showed a deeper engagement with science content, with particular awareness of how the inquiry science pedagogical strategy affected their engagement with the science content. As a result of this programme, the students demonstrated improved knowledge of rehabilitation processes. Students' knowledge was tested at the end of the programme through a "card shuffle" activity, where the students moved around a collection of cards which each represented a step involved in land rehabilitation post-mining; for example, "test the $\mathrm{pH}$ of the soil", "hand seeding", or "bank the top-soil". The students then drew linking arrows to finalise their group's "model" of the rehabilitation process that they had conducted. Teachers and university staff monitored the students' group work and listened to the discussions between group members as they negotiated their point of view relating to where each step belonged and how they were linked. When each group had completed their model, they presented it to the other groups, who asked questions about the model that required each group to justify their understanding. Not every model was the same; however, every group was able to clearly articulate the justification for their model based on sound scientific understandings.

\section{Provide Students with Concrete Experiences}

Avery's (2013) third strategy in the LRK model is to "provide students with concrete experiences" that engage with the broader science community to inspire "rural students' STEM interests and pursuits" (p. 32). In this programme, the students worked alongside experienced science educators and scientists with expertise in plant ecology and land rehabilitation from the university. They also worked closely with an indigenous elder who spoke 
about the need for rehabilitation and how the local indigenous community wanted students to stay as part of the community and care for the land even after mining. The elder also showed students animal tracks and native plants, enhancing the students' connection to the land. He shared the names of the local flora, the indigenous uses of each part of each plant, and the observable cycle that each plant would go through depending on the local conditions. Through engaging with the elder, the students began to understand the reciprocity between people and country. The students were able to contrast their understanding of this relationship that shows respect for the land with contemporary industrial interactions that resulted in the degraded land they were attempting to rehabilitate.

The students enjoyed their time with the elder to give them a second perspective on the importance of rehabilitation, "I think it was really good cos [sic] we weren't just focussing on one use or aspect; we were [focussing on culture as well as science]". They were in awe of the amount of history the elder could share with them about the land; "he was really good and knew the heritage and everything ... I enjoyed having him out there. It was really good and it was definitely a different perspective and the importance of the sites and everything".

Similarly, students spoke about the amount of new content knowledge they learned from working with the university science educators and scientists. The students reflected on how it helped their analytical development:

The main thing that stood out for me was kind of analysing what you have and finding out the best solution with it. So for us, like we said earlier, we had this plot and we kind of had to like okay, so this soil is a little too hard, we can't plant it there. This soil needs work or the water won't get in. This soil is a little softer and more moist - we can plant there. So mostly the main thing that sticks out for me personally was the analytical side of this.

The students also shared their perspective on the scientist and how he differed from the stereotype; "The scientist ... He's really nice about everything. He's like more laidback than a lot of other people. And he explains things well".

They also shared feedback on how families had become involved in the learning. Families were either directly interested in the content that the students were learning, or in the studentcentred pedagogy that was being used. One student explained how her sister was really excited about what she was doing in science:

I've told a few friends and of course my sister and she was really interested cos [sic] she really likes plants and she gardens a lot and she was like going into our garden and finding samples actually herself because she's really interested in this and then she was analysing the data as well, which is good. She might even be more enthusiastic than me.

Other students explained their families' interest in the pedagogical approach; "I told my Mum about it and she got really excited because she likes when we ... I concentrate better and learn better when I'm doing experiments and things." Another student said:

I told my Dad and he was pretty interested and I told him all the activities that we did and then hopefully you guys [from the university] will come back later this year and we'd go out again and see if anything grew and then I told him again in class like what grew and everything. Yeah, and he's pretty impressed with that.

In engaging with a variety of people, the students had shaped their views of science and learning in science. One student spoke about authentic learning and how the project connected 
with the community; "I don't like Physics. I think the hands-on thing, definitely with minerals and everything, you can relate it. I grew up on a farm. It's pretty important that you understand all of that". They also thought the experience built aspiration for tertiary study as, "it was a pretty good experience to work with a university". One student summarised the collective sentiment by saying:

It's a benefit as [an academic extension] program to do this and working with a university I think we get to, not really see what it's like, but kind of at the same time

... I think the gardening part of it was pretty fun and I think we took away from that physical lessons as well as social lessons.

The qualitative data show how the LRK programme had a diverse impact on students and broadened their experience with the local and science community enabling clear links to be drawn about how STEM subjects are directly linked to and benefit the local community.

\section{Discussion}

In this study, an approach to STEM and gifted and talented education that explicitly connected local indigenous and regional issues was trialled with lower secondary academically talented students. In measuring the typical classroom experiences for this sample of students, it was evident that they had similar experiences to urban and non-gifted students, with just $50 \%$ of students stating they never get the opportunity to design their own experiments (Danaia et al. 2013). However, the students in the rural school setting had higher levels of interest and curiosity in science when compared to the (Danaia et al. 2013) study, with $84 \%$ of the rural students stating that they were never or sometimes bored compared to $55 \%$ of urban, nongifted students.

While the sample in this study was curious and interested in science, the feedback collected through focus groups suggested that the students found the rehabilitation experience to be beneficial and engaging in many respects. Students highly valued the practical and hands-on nature of the programme in comparison to their typical classroom experiences, consistent with Avery's (2013) strategy of providing students with concrete experiences. Conducting science in the field with experienced scientists was highly engaging, and using sustainability issues as a context for learning linked to the gifted and talented students' sense of social justice and their need to situate learning within the "bigger picture" (Harrison 2004; Merrick and Targett 2004). Furthermore, the students trusted in the quality of information and learning because of their engagement with university scientists and science educators alongside their regular classroom teacher, which is important in establishing positive relationships between teachers and students within gifted education (Hertberg-Davis and Callahan 2008; Mullet et al. 2018; Siegle et al. 2014).

The rehabilitation experience not only connected students to the local landscape and their LRK, but also embedded sustainability and environmental education. Avery's (2013) strategy of scaffolding content and pedagogy was evident in the way the content of the programme was structured for students to develop links between understanding rehabilitation, STEM inquiry, and the impact on the broader community. The students openly discussed the importance of land rehabilitation after mining and began to articulate the challenges in rehabilitation, making links between inquiry science and the actioning of STEM within an authentic context (ACARA n.d.). The discussion on land rehabilitation was enhanced by the connection to local indigenous knowledge and their experiences with the elder. The local elder engaged the 
students from the first learning activity and provided an explicit connection to country, its plants, animals, seasons, and a sense of place shared by the students, as well as insights into the economic benefit of mining to the local community.

Not only did the students engage with the university scientists and local elder, they also bought plants from a local nursery to extend their connections with the local community and enhance science and mathematics learning. Integrating these local experiences with the STEM learning reinforced the importance of contextualised authentic science-based learning (Avery and Kassam 2011; Goodrum et al. 2012) as well as the importance of addressing LRK by including all forms of local knowledge, including indigenous perspectives (Avery 2013). Furthermore, this type of learning is consistent with addressing the pillars of sustainability outlined by UNESCO (Benson Whalén 2012) and embedded within the Australian Curriculum (ACARA n.d.).

A key issue for rural students is the perception that in order to be successful, they need to leave their local community (Carr and Kefalas 2009). By connecting students to the local community and through their participation in a programme of work that affected change within the community, this study aimed to promote success by staying and investing in the community. The sense of connection to place and people was evidenced by the students' discussions about the project with family and friends. These discussions enhanced the learning experience as many family members were involved in the mining sector and these discussions extended students' understanding of the impact of mining on the local land. The students began to encourage families to invest in the learning with them and exhibited a sense of custodianship to the land on which they were working as they visited their sites on multiple occasions. Building emotional connections to both people and place could be a strategy to retaining students in rural communities.

While data were not collected from teachers in addressing their response to the teacherbased professional development strategy of Avery's (2013) LRK model, there was anecdotal evidence that the partnership between the university, local community, and school community did have an impact on the teaching staff at the school. The co-design and implementation of the programme resulted in high teacher participation in the study, and the students' qualitative data provided supporting evidence of a change in pedagogy when the LRK model was implemented. The long-term impacts of LRK on teachers' programming and pedagogy are an area for future research.

\section{Limitations}

Sustaining partnerships with rural communities has a significant cost for metropolitanbased universities. For example, flights to rural areas from major cities in Australia are costly, and a practical programme, such as the one implemented in this study, requires multiple trips so that students and scientists can be in the field together and monitor the programme over time. A strategy to overcoming the financial cost of these types of programmes would be to do initial fieldwork together and then monitor the process remotely using information and communication technologies. However, the implications of this type of process would need to be evaluated as the students in this study cited the personal interactions with the scientist and science educators as a highly engaging and beneficial aspect to the study. In addition to travel costs, there are also significant costs in equipment and testing of samples in this programme. Obtaining appropriate insurance 
and permission to work on degraded land were other expenses that need to be considered in this type of research, and while this adds richness to the students' experiences, it also adds time delays and financial costs to the study. These challenges all impact the teachers' professional learning and are barriers that need to be overcome when conducting authentic STEM learning programmes in rural settings. Overcoming these barriers is important as rural schools tend to receive less funding (Williams 2010) but suffer higher costs per student (Sipple and Brent 2008), and this may have a negative impact on the types of learning experiences afforded to these students.

Furthermore, the data collected in this study centred on the student experience. However, the essential involvement of the teachers in delivering the programme warrants further investigation. Data collected from teachers would add to the richness of the evaluation and would strengthen the efficacy of teacher place-based professional development strategies.

In addition, the three LRK strategies discussed in this paper represent the teacher level of Avery's (2013) model. Avery (2013) also provides strategies for student-level intervention and community-level practice. These levels were not an explicit focus of this study, and therefore, the feasibility of implementing strategies across all three levels may result in different findings compared to this study.

\section{Conclusion}

This small-scale study explored academically gifted students' engagement and learning in STEM through their participation in a LRK programme conducted in their local community. Avery's (2013) LRK model was employed as a theoretical framework for the study. Quantitative data were first collected to determine the typical experiences of the academically gifted students. While the students were generally more curious and interested in science than urban students, they had similar classroom experiences to urban and non-gifted students (Danaia et al. 2013). Qualitative data collected around the programme showed that the experience was highly engaging and improved learning. The students commented on how they found that they retained knowledge better as a result of the practical fieldwork undertaken with the university scientist and science educators. They began to make connections that extended STEM knowledge to consider science as a human endeavour (ACARA 2015; Goodrum et al. 2012) and as essential to improving their local community.

While this study only employed the teacher level of Avery's (2013) strategies, it does begin to provide evidence of the feasibility and success of applying the LRK model. Using sustainability and land rehabilitation was a good driver for connection to local rural knowledge, as the students had ongoing experience with this issue through the prevalence of mining in the local area. Not only were students able to connect learning to their lived experiences but they also engaged families and friends in their learning, in addition to their school-based experiences. However, the research did identify barriers in using LRK in university and rural school partnerships, especially in the financial costs experienced when urban-based scientists and science educators are travelling to undertake fieldwork with rural-based students. Overcoming these challenges to provide quality LRK and STEM learning experiences for students is an area for further research and would improve the capacity for rich and authentic STEM experiences to be delivered to all rural students, including those who are academically gifted. 


\section{Compliance with Ethical Standards}

Ethics clearance from the university's Human Research Ethics Committee was provided prior to any data collection.

Open Access This article is distributed under the terms of the Creative Commons Attribution 4.0 International License (http://creativecommons.org/licenses/by/4.0/), which permits unrestricted use, distribution, and reproduction in any medium, provided you give appropriate credit to the original author(s) and the source, provide a link to the Creative Commons license, and indicate if changes were made.

Publisher's Note Springer Nature remains neutral with regard to jurisdictional claims in published maps and institutional affiliations.

\section{References}

ACARA. (2015). The Australian curriculum: science. Retrieved from http://www.australiancurriculum.edu. $\mathrm{au} / \mathrm{science} /$ rationale

ACARA. (n.d.). Cross-curriculum priorities. Retrieved from http://www.australiancurriculum.edu. au/CrossCurriculumPriorities

Akerson, V. L., Burgess, A., Gerber, A., Guo Khan, T. A., \& Newman, S. (2018). Disentangling the meaning of STEM: implications for science education and science teacher education. Journal of Science Teacher Education, 29(1), 1-8.

Alcott, B., \& Rose, P. (2015). Schools and learning in rural India and Pakistan: who goes where, and how much are they learning? Prospects, 45(3), 345-363. https://doi.org/10.1007/s11125-015-9350-5.

Australian Bureau of Statistics. (2011). Australian statistical geography standard. Australia: Canberra.

Avery, L. M. (2013). Rural science education: valuing local knowledge. Theory Into Practice, 52(1), 28-35. https://doi.org/10.1080/07351690.2013.743769.

Avery, L. M., \& Kassam, K. A. (2011). Phronesis: children's local rural knowledge of science and engineering. Journal of Research in Rural Education, 26, 1-18.

Benson Whalén, C. (2012). UN adviser proposes four pillars for post-2015 goals. Retrieved from http://sdg.iisd. org/news/un-adviser-proposes-four-pillars-for-post-2015-goals/

Carr, P., \& Kefalas, M. J. (2009). The rural brain drain. Retrieved from http://chronicle.com/article/The-RuralBrain-Drain/48425/.

Chiu, A., Price, C. A., \& Ovrahim, E. (2015). Supporting elementary and middle school STEM education at the whole school level: a review of the literature. Paper presented at NARST 2015 Annual Conference, Chicago, IL.

Christensen, R., Knezek, G., \& Tyler-Wood, T. (2015). Alignment of hands-on STEM engagement activities with positive STEM dispositions in secondary school students. Journal of Science Education and Technology, 24(6), 898-909.

Cohen, R. L., \& Sandberg, T. (1977). Relation between intelligence and short-term memory. Cognitive Psychology, 9, 534-554.

Croft, L. J. (2003). Teachers of the gifted: gifted teachers. In N. Colangelo \& G. A. Davis (Eds.), Handbook of gifted education (pp. 558-571). Boston: Allyn \& Bacon.

Croft, L. J., \& Wood, S. M. (2015). Professional development for teachers and school counselors: empowering a change in perception and practice of acceleration. In S. G. Assouline, N. Colangelo, J. VanTassel-Baska, \& A. Lupkowski-Shoplik (Eds.), A nation empowered: evidence trumps the excuses holding back America's brightest students (pp. 87-98). Iowa City: The University of Iowa.

Danaia, L., Fitzgerald, M. T., \& McKinnon, D. H. (2013). Students' perceptions of high school science: What has changed over the last decade? Research in Science Education, 43(4), 1501-1515.

Danaia, L., McKinnon, D. H., \& Fitzgerald, M. (2017). Ideal pictures and actual perspectives of junior secondary school science: comparisons drawn from Australian students in an astronomy education programme. Research in Science and Technological Education, 1-16. https://doi.org/10.1080 /02635143.2017.1344959.

Davidson, J. E. (1986). The role of insight in giftedness. In R. J. Stenberg \& J. E. Davidson (Eds.), Conceptions of giftedness (pp. 201-222). Cambridge, England: Cambridge University Press. 
Department of Foreign Affairs and Trade. (2017). Composition of trade: Australia 2016-2017. Retrieved from Canberra, Australia: http://dfat.gov.au/about-us/publications/Documents/cot-2016-17.pdf

Department of the Environment and Energy. (2017). Australian energy update 2017. In Retrieved from https:/www.environment.gov.au/system/files/resources/f02a388d-74eb-4200-96fb-fe2a9d0caf5 b/files/energy-update-report-2017.pdf.

Dieker, L., Grillo, K., \& Ramlakhan, N. (2012). The use of virtual and simulated teaching and learning environments: inviting gifted students into science, technology, engineering, and mathematics careers (STEM) through summer partnerships. Gifted Education International, 28, 96-106. https://doi. org/10.1177/0261429411427647.

Dyment, J. E., \& Hill, A. (2015). You mean I have to teach sustainability too? Initial teacher education students' perspectives on the sustainability cross-curriculum priority. Australian Journal of Teacher Education, 40(3), 21-35. https://doi.org/10.14221/ajte.2014v40n3.2.

Fitzgerald, M., Danaia, L., \& McKinnon, D. H. (2017). Barriers inhibiting inquiry-based science teaching and potential solutions: perceptions of positively inclined early adopters. Research in Science Education, 1-24.

Flannery, T. (2010). Here on earth: an argument for hope. Melbourne, Australia: The Text Publishing Company.

Freeman, J. (Ed.) (1985). The psychology of gifted children. New York: John Wiley.

Goodrum, D., Druhan, A., \& Abbs, J. (2012). The status and quality of year 11 and 121 science in Australian schools. Retrieved from https://www.science.org.au/supporting-science/science-sector-analysis/reports-andpublications/status-and-quality-year-11-and

Guilford, A., Scheuerle, J., \& Schonburn, S. (1981). Aspects of language development in the gifted. Gifted Child Quarterly, 25, 159-163.

Halsey, J. (2017). Independent review into regional, rural and remote education: discussion paper. Retrieved from Canberra, Australia: https://docs.education.gov.au/node/44526

Harrison, C. (2004). Giftedness in early childhood: the search for complexity and connection. Roeper Review, 26(2), 78-84.

Hertberg-Davis, H., \& Callahan, C. M. (2008). A narrow escape: gifted students' perceptions of advanced placement and international baccalaureate programs. Gifted Child Quarterly, 52, 199-216. https://doi. org/10.1177/0016986208319705.

Hertzog, N. B. (2003). Impact of gifted programs from the students' perspectives. Gifted Child Quarterly, 47, 131-143. https://doi.org/10.1177/001698620304700204.

Johnson, C. C, Peters- Burton, E. E., \& Moore, T. J. (2015). STEM road map: a framework for integrated STEM education. London, UK: Taylor and Francis.

Lazonder, A. W., \& Harmsen, R. (2016). Meta-analysis of inquiry-based learning. Review of Educational Research, 86(3), 681-718.

Lummis, G. W., Morris, J. E., Lock, G., \& Odgaard, J. C. (2015). Where Western Australian graduate diploma of education primary students source their information on sustainability. Australian Journal of Teacher Education, 40(10), 51-65.

Marginson, S., Tytler, R., Freeman, B., \& Roberts, K. (2013). STEM country comparisons: international comparisons of science, technology, engineering and mathematics (STEM) Education Retrieved from http://www.utas.edu.au/_data/assets/pdf_file/0004/391648/stem_country_comparisons_13.pdf

Means, B., Wang, H., Wei, X., Lynch, S., Peters, V., Young, V., \& Allen, C. (2017). Expanding STEM opportunities through inclusive STEM-focused high schools. Science Education, 101(5), 681-715.

MCEETYA. (2008). Melbourne declaration on educational goals for young Australians. Melbourne, Australia: Ministerial Council on Education, Employment, Training and Youth Affairs (MCEETYA).

Merrick, C., \& Targett, R. (2004). Gifted and talented education: professional development package for teachers, early childhood: module 2 . Sydney, Australia: GERRIC.

Miles, M., \& Huberman, A. (1994). An expanded sourcebook: qualitative data analysis (2nd ed.). London, England: Sage Publications.

Monk, D. H. (2007). Recruiting and retaining high-quality teachers in rural areas. The Future of Children, 17(1), $155-174$

Morse, J. M., Niehaus, L., Wolfe, R. R., \& Wilkins, S. (2006). The role of the theoretical drive in maintaining validity in mixed-method research. Qualitative Research in Psychology, 3(4), 279-291. https://doi. org/10.1177/1478088706070837.

Mullet, D. R., Kettler, T., \& Sabatini, A. (2018). Gifted students' conceptions of their high school STEM education. Journal for the Education of the Gifted, 41(1), 60-92. https://doi.org/10.1177 $/ 0162353217745156$.

National Assessment Program: Scientific literacy. (2003-2012). National reports: scientific literacy.

National Research Council. (2002). Learning and understanding: improving advanced study of mathematics and science in U.S. high schools. Retrieved from Washington, DC: http://goo.gl/c5NiVD 
National Science Board. (2014). Science and engineering indicators. Retrieved from https://www.nsf. gov/statistics/seind14/content/digest/nsb1402.pdf

Odgaard, J. C. (2014). Western Australian graduate diploma of education (primary) students' perceptions of sustainability. (Doctoral dissertation), Edith Cowan University, Perth, Australia.

Office of the Chief Scientist. (2014). Science, technology, engineering and mathematics: Australia's future. Retrieved from Canberra, Australia. Retrieved from http://www.chiefscientist.gov.au/2014/09/professorchubb-releases-science-technology-engineering-and-mathematics-australias-future/

Organisation for Economic Co-operation and Development. (2016). PISA 2015 results: excellence and equity in education. Retrieved from http://www.oecd.org/.../pisa-2015-results-volume-i-9789264266490-en.htm

Parker, C.E., Pillai, S., \& Roschelle, J. (2016). Next generation STEM learning for all: a report from the NSF supported forum. Waltham, MA: Education Development Center.

Parkinson, M. L. (1990). Finding and serving gifted preschoolers. Understanding Our Gifted, 2(5), 10-13.

Punch, K. F. (2014). An introduction to social research: quantitative and qualitative approaches (3rd ed.). London, United Kingdom: Sage Publishing.

Rennie, L., Goodrum, D., \& Hackling, M. (2001). Science teaching and learning in Australian schools: results of a national study. Research in Science Education, 31(4), 455-498.

Sachs, J. D. (2012). From millennium development goals to sustainable development goals. The Lancet, 379, 2206-2211.

Schafft, K. A., \& Jackson, A. (Eds.). (2011). Rural education for the twenty-first century: identity, place, and community in a globalizing world. University Park, PA: Penn State University Press.

Schwandt, T. A. (2000). Three epistemological stances for qualitative inquiry: interpretivism, hermeneutics, and social constructionism. In N. K. Denzin \& Y. S. Lincoln (Eds.), Handbook of qualitative research. Thousand Oaks, CA: Sage Publications.

Siegle, D., Rubenstein, L. D., \& Mitchell, M. S. (2014). Honors students' perceptions of their high school experiences: the influence of teachers on student motivation. Gifted Child Quarterly, 58, 35-50. https://oi. org/10.1177/0016986213513496.

Sipple, J. W., \& Brent, B. O. (2008). Challenges and opportunities associated with rural school settings. In H. F. Ladd \& E. B. Fiske (Eds.), Handbook of research in education finance and policy (pp. 612-629). New York, NY: Routledge.

Skamp, K. (2012). Teaching primary science: trial-teacher feedback on the implementation of PrimaryConnections and the 5E model. Retrieved from Canberra, Australia: https://primaryconnections. org.au/sites/default/files/files/TeachingPrimaryScience2012_Report.pdf

Taylor, T., \& Milton, M. (2006). Preparation for teaching gifted students: an investigation into university courses in Australia. Australiasian Journal of Gited Education, 15(1), 25-31.

Thomson, S., De Bortoli, L., \& Underwood, C. (2016a). PISA 2015: a first look at Australia's results. Retrieved from Melbourne, Australia: https://research.acer.edu.au/ozpisa/21

Thomson, S., Wenert, N., O’Grady, E., \& Rodrigues, S. (2016b). TIMSS 2015: a first look at Australia's results. Retrieved from Melbourne, Australia: https://research.acer.edu.au/timss_2015/1/

Townsend, A., McKinnon, D. H., Fitzgerald, M., Morris, J., \& Lummis, G. (2016). Educative curricula and PCK development driven by STEM professional learning in rural and remote schools: A longitudinal type IV case study. International Journal of Innovation in Science and Mathematics Education, 24(4), 1-17.

Tytler, R. (2007). Re-imagining science education engaging students in science for Australia's future. Australian Education Review, 51, 1-77.

VanTassel-Baska, J., \& Hubbard, G. (2015). Serving the rural gifted child through advanced curriculum: a challenge of geography. In T. Stambaugh \& S. Woods (Eds.), Serving gifted students in rural settings (pp. 155-177). Waco: Prufrock Press.

Walsh, R. L., Kemp, C. R., Hodge, K. A., \& Bowes, J. M. (2012). Searching for evidence-based practice: a review of the research on educational programs for intellectually gifted children in the early childhood years. Journal for the Education of the Gifted, 35(2), 103-128. https://doi.org/10.1177/0162353212440610.

Williams, D. T. (2010). The rural solution: how community schools can reinvigorate rural education. Washington, DC: Centre for American Progress. 